\title{
Chapter 6 \\ Labour-Intensive Industrialization and the Emerging State in Pre-war Japan
}

\author{
Masayuki Tanimoto
}

\subsection{Introduction}

It is widely asserted that the "success" of emerging states in Asia rested on the adoption of a development strategy based on export-oriented instead of import-substitution industrialization. In fact, the growth of export trade that started with labour-intensive products seems to have played a significant role in fostering the emerging economies and states beginning in the 1970s, especially in East and Southeast Asia.

On the other hand, it is also widely known that the Meiji government, established through the Meiji Restoration in 1868, adopted "Shokusan-kogyo seisaku", or the economic policy of encouraging new industries as a means of catching up with the "advanced" states in the West. In fact, the government tried to transplant brand-new industrial technologies and institutions, such as mechanized cotton spinning mills, iron works, shipyards, arsenals, and so on. It is clear that these newly transplanted and more or less capital-intensive industries targeted to promote import substitution. If they played a central role for Japan's economic development after the Meiji Restoration from 1868 onwards, how can we evaluate the role of export-oriented industrialization in Japan's development, a distinctive example of emerging state prior to WWII?

Based on the recent literature discussing the multi-layered nature of Japan's economic development, ${ }^{1}$ this chapter reconsiders the significant role of labour-intensive industrialization in pre-war Japan. In doing so, the chapter specifically examines its

\footnotetext{
${ }^{1}$ In regard with the term "multi-layered nature of Japan's economic development", see Sawai and Tanimoto (2016), 148-149. I also keep the discussion about "balanced growth", initiated by Takafusa Nakamura, in mind. See Nakamura (1971/1983).

M. Tanimoto ( $\varangle)$

Graduate School of Economics, Faculty of Economics, The University of Tokyo,

Bunkyo-ku, Tokyo 113-0033, Japan

e-mail: tanimoto@e.u-tokyo.ac.jp

K. Otsuka and K. Sugihara (eds.), Paths to the Emerging State in Asia and Africa,

Emerging-Economy State and International Policy Studies,

https://doi.org/10.1007/978-981-13-3131-2_6
} 
role in import and export trade, to which the discussion of the development strategy mentioned above pays special attention. After an overview of the features of Japan's economic development, the chapter demonstrates the role of labour-intensive industrialization by exemplifying cases of cotton related industries, followed by a discussion on the changing pattern of export-oriented industries, with a focus on urban small-scale manufacturers. The last section touches on the prospects in the post-war period.

\subsection{The Nature of Industrialization in Modern Japan}

According to Fig. 6.1, Japan's per capita GDP nearly reached the level of those in industrialized Western states in the 1970s through the so-called "rapid growth era" in the late 1950s and the 1960s. Although this post-war economic growth is eyecatching, the figure also reveals the catching up process of Japan's per capita GDP before World War II, starting from a level of less than one-quarter of that of the U.K., the most advanced state in terms of economic development, and around $40 \%$ of those of France and Germany, relatively backward states which were trying to catch up to the U.K. in the 1870s and the 1880s. The pre-war economic growth achieved $40 \%$ of the GDP of the U.K. and around 50\% of those of France and Germany in the 1930s. The speed of catching up was more rapid in terms of the state's total GDP, reflecting the relatively high population growth in Japan. Considering the destructive effect of World War II on Japan's economy, the post-war rapid growth can be positioned as the last stage of the long-term catching up process that continued from the second half of the nineteenth century. In other words, Japan can be regarded as an emerging state, at least in the early twentieth century, whose growth was "trapped" in the 1940s and the early 1950s. In this regard, Japan's pre-war experience deserves to be explored in light of the emerging state argument.

The next concern is a question as to whether the focus on labour-intensive sectors deserves a better understanding in Japan's industrialization. One way to approach this question is to consider the relative contribution of labour-intensive sectors to overall Japanese production. Since it is difficult to estimate the relative weight in valueadded terms, we will use the contribution to employment as a way to approach this problem. Table 6.1 shows the estimated composition of manufacturing workers by employment size in 1909. Among 3,337 million people occupied in the manufacturing sectors, only 0.92 million workers were affiliated with "factories" employing five workers and more, or established by the government. In other words, approximately $70 \%$ of the manufacturing work force was working in industrial sites recognized as non-factory workshops. A similar estimation for the year after the rapid growth during World War I, based on the first national census of population carried out in 1920, also reveals the dominance of small workshops in manufacturing sectors. Among the total working population engaged in the manufacturing sectors, approximately 4.56 million, $62.9 \%$ of the total working population were engaged in non-factory workshops (Tanimoto 2006, 6). Since the strong positive correlation between firm 


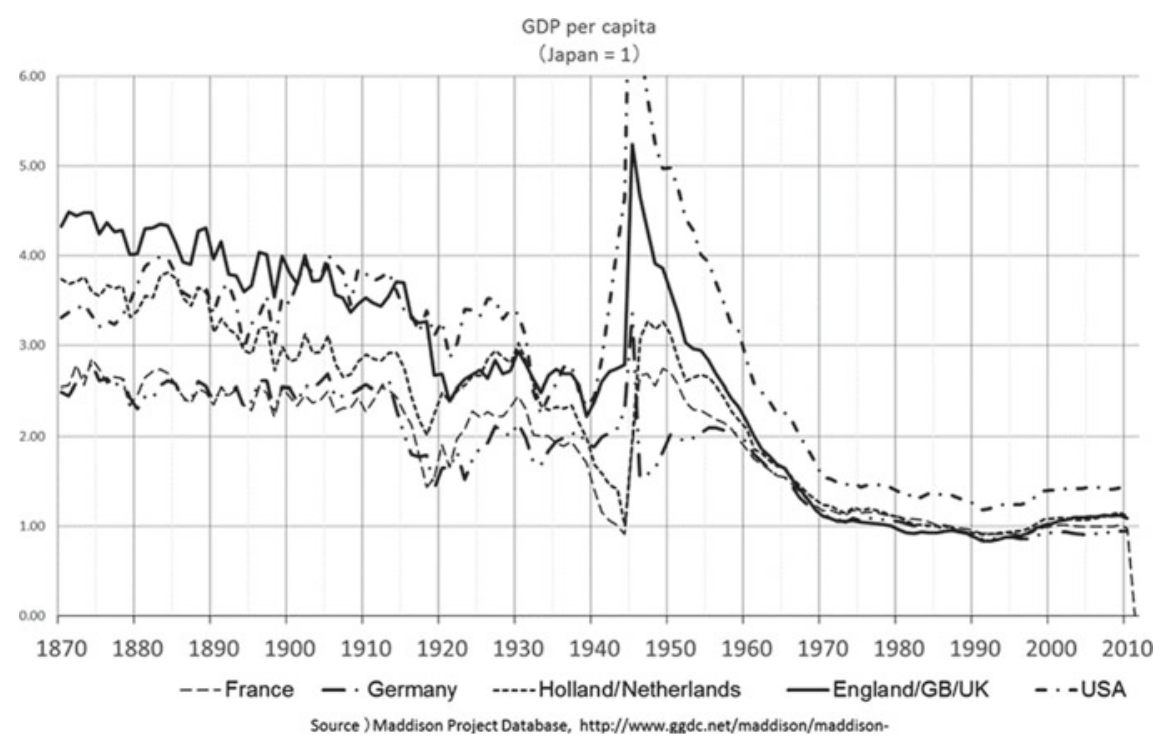

Fig. 6.1 GDP per capita in comparison with Japan

Table 6.1 Distribution of working population of manufacturing industries in 1909

\begin{tabular}{|c|c|c|c|c|c|c|c|}
\hline & \multirow[t]{3}{*}{ Total } & \multirow{3}{*}{$\begin{array}{l}\begin{array}{l}\text { Non- } \\
\text { factory }\end{array} \\
\text { Total }\end{array}$} & \multicolumn{5}{|l|}{ Factory } \\
\hline & & & \multicolumn{3}{|c|}{ Private sector } & \multicolumn{2}{|c|}{$\begin{array}{l}\text { Government-run } \\
\text { factory }\end{array}$} \\
\hline & & & Total & $\begin{array}{l}\text { 5-9 } \\
\text { employ- } \\
\text { ees }\end{array}$ & $\begin{array}{l}1,000 \text { or } \\
\text { more } \\
\text { employ- } \\
\text { ees }\end{array}$ & Total & $\begin{array}{l}1,000 \text { or } \\
\text { more } \\
\text { employ- } \\
\text { ees }\end{array}$ \\
\hline Male & $2,030,600$ & $1,630,586$ & 307,139 & 66,275 & 30,537 & 92,875 & 81,466 \\
\hline Female & $1,306,500$ & 788,618 & 493,498 & 42,141 & 80,742 & 24,384 & 23,528 \\
\hline Total & $3,337,100$ & $2,419,204$ & 800,637 & 108,416 & 117,259 & 116,385 & 104,994 \\
\hline $\begin{array}{l}\text { Proportion } \\
\text { of female } \\
\text { (\%) }\end{array}$ & 39.2 & 32.6 & 61.6 & 38.9 & 72.6 & 20.8 & 22.4 \\
\hline
\end{tabular}

Source Noshomusho ed, Kojotokeisohy, Noshomutokeihyo and Honpokogyoippan, Umemura et al. (1988)

size and capital intensity is confirmed by the industrial survey conducted in 1932 in Tokyo, the prefecture comprising the largest manufacturing population from the 1920s onwards, it is plausible to use employment size as a proxy for labour intensity in working sites (Tanimoto 2013a, 156). Thus, it is clear that Japan's pre-war industrialization entailed the proliferation of labour-intensive sectors, at least in a quantitative sense. 


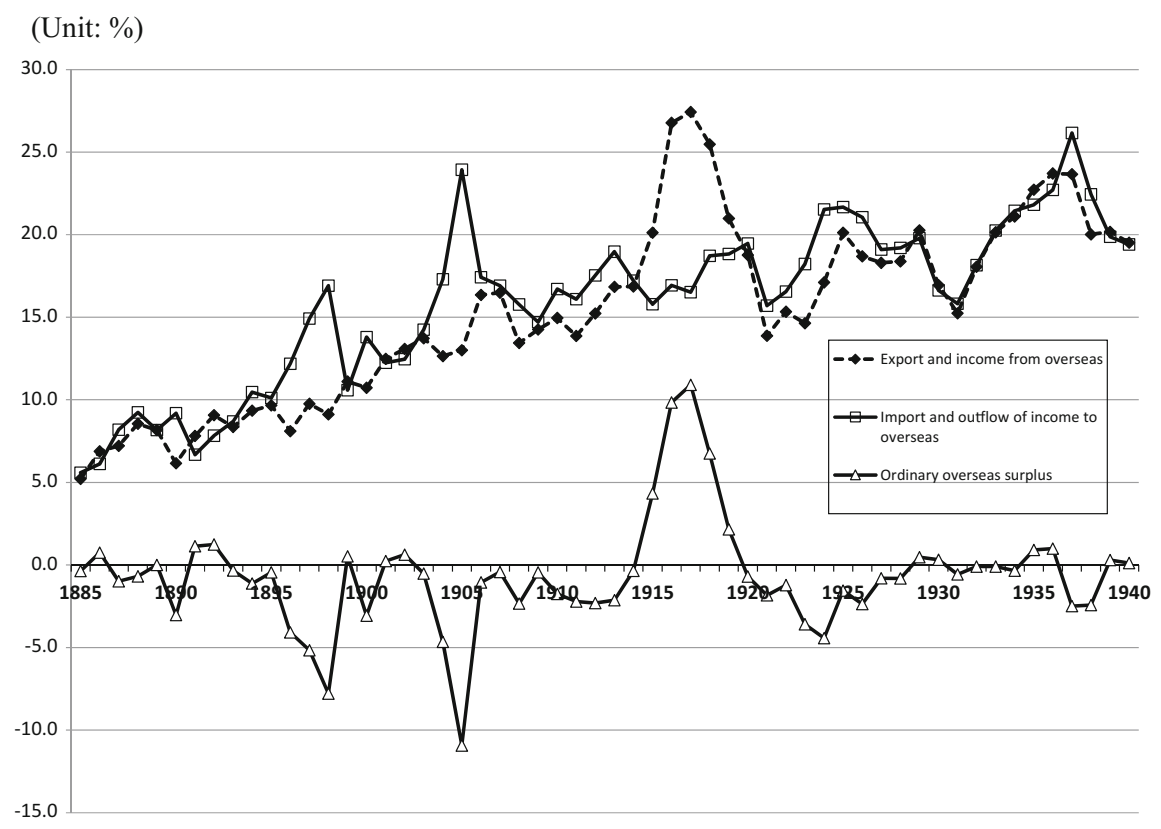

Fig. 6.2 Japan's export, import and trade balance against GNP. Source Ohkawa et al. (1974)

The contribution of labour-intensive sectors in Japan's international trade is also worth discussing. As Fig. 6.2 suggests, the degree of dependence upon foreign trade, the total value of export and import per GDP, rose along with GDP growth. On top of that, the trade balance tended toward imbalance except during specific periods, and the margin of the imbalance occasionally grew significantly. The structural change of trade is also worth noticing. According to the overviewing of the trade based on the estimated long-term statistics, the main import commodities changed from finished manufactured goods to intermediate and capital goods, followed by an increase in raw materials in tandem with the development of the manufacturing sectors. The expenditure for these imported commodities should have been financed by revenue from the export trade, from mining products such as copper and coal, to silk related commodities and newly developed manufactured products (Yamazawa and Yamamoto 1979: 5-9). The changing role of the labour-intensive sectors can be effectively examined by observing the trade related aspects, touching on a discussion of the effect of import-substitutive and export-oriented strategies. 


\subsection{The Role of Labour-Intensive Sectors in Pre-war Japan}

\subsubsection{The Cotton Industry for Import Substitution ${ }^{2}$}

It is well known that the Opening of the Ports in 1859, the end of the "seclusion policy" of Tokugawa Shogunate, had a great impact on the cotton industry in Japan's archipelago. In fact, the increase in English cotton cloth grew to occupy nearly $40 \%$ of the domestic market for cotton cloth in the early 1870s. However, the proportion of imported cotton cloth to domestic cotton demand had begun to decrease in the mid1870 s, and fell to around $10 \%$ before 1880 . On the other hand, as Table 6.2 shows, the volume of imported cotton yarn exceeded cotton cloth during the latter half of the 1870s. This transformation, from importing finished goods to intermediate goods, suggests a structural change in the production aspects of cotton goods in Japan's archipelago.

What happened were drastic re-organizations of the industry. The importation of cotton yarn almost eliminated domestic hand-spun yarn from the yarn market. Naturally, as it provided material for spinning, cotton cultivation also suffered. However, it was not before the late 1880s that cotton cultivation in Japan had clearly declined, since the self-use of cotton for spinning and weaving continued in a certain portion of peasant households. It was the penetration of 'new' cotton cloths produced in the domestic weaving districts, which were relatively cheap as well as suitable to consumers in Japan, that ruled out the self-use production of cloth in the rural areas. The appearance of these 'new' cloths showed the consequences of the re-organization of the cotton weaving districts, the other phase of re-organization of the cotton industry.

Unlike imported cloth, imported yarn that came from England at the early stage, followed by British Indian yarn in the next stage, provided weaving districts with the opportunity to survive, or even develop. The relative low price of machine-made imported yarn enabled the weaving districts to realize competitive prices compared to imported cloth, as well as to develop a new kind of cloth, whose quality was different from those made of hand-spun yarn (Tamura 2004). The import substitution of the cloths can be accounted for by the response of these weaving districts, and these districts could have been prosperous under the circumstances of the market expansion for cloth in the 1870s. Based on this transformation, Japan's cotton industry started development of both weaving and spinning sectors. The former provided the market that was indispensable for establishment of the latter. However, there was a huge difference in terms of the production form within the industry. Regarding this as a multi-layered structure, we will see their development from the 1880 s onwards in the light of labour-intensive industrialization.

When it comes to the cotton weaving industry, producers were divided into two different categories. One comprised weaving mills that were attached to the cotton spinning companies that emerged in the late 1880s, at the earliest. Such mills were equipped with British or North American power looms, and they employed numerous

\footnotetext{
${ }^{2}$ The first half of this section is based on Tanimoto (2006, 2009).
} 


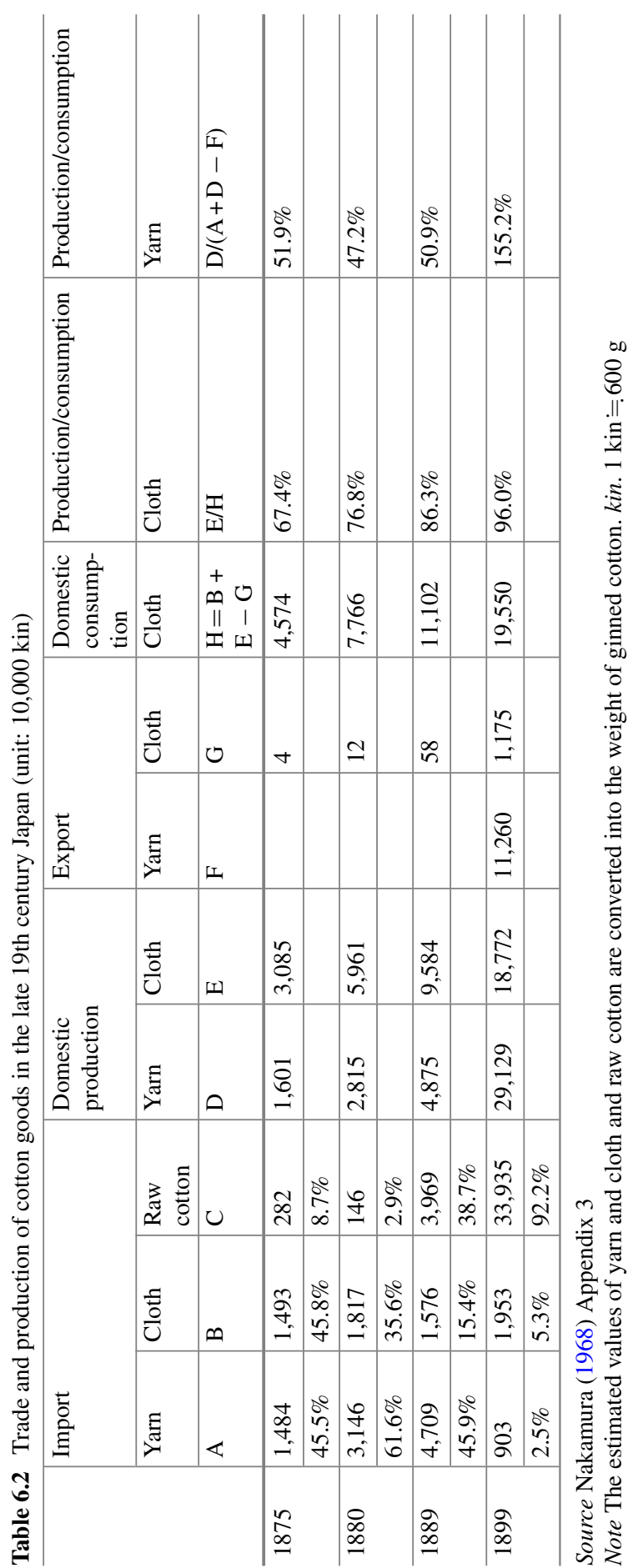


Table 6.3 Distribution of businesses and workers by production forms of weaving industry in 1905

\begin{tabular}{|c|c|c|c|c|c|}
\hline & \multirow[t]{3}{*}{ Total } & \multicolumn{4}{|c|}{ Form of production } \\
\hline & & \multicolumn{3}{|c|}{ Independent business } & \multirow{2}{*}{$\begin{array}{l}\text { Piece rate } \\
\text { weaving }\end{array}$} \\
\hline & & Factory & Workshop & Clothier & \\
\hline $\begin{array}{l}\text { Number of } \\
\text { business }\end{array}$ & 448,609 & 3,097 & 138,833 & 14,370 & 292,309 \\
\hline $\begin{array}{l}\text { Number of } \\
\text { workers }\end{array}$ & 767,423 & 91,279 & 229,446 & 58,591 & 388,107 \\
\hline $\begin{array}{l}\text { Proportion of } \\
\text { female } \\
\text { workers }\end{array}$ & 95.3 & 88.5 & 95.7 & 89.4 & 97.6 \\
\hline $\begin{array}{l}\text { Worker per } \\
\text { business }\end{array}$ & 1.7 & 29.5 & 1.7 & 4.1 & 1.3 \\
\hline
\end{tabular}

Source Noshomusho ed, Noshomutokeihyo

young female workers, just like the cotton spinning mills that we will discuss later. This type represents a factory system directly transplanted from Western countries (Takamura 1971; Nakaoka 2006). However, this production system produced at most only about one-third of the total output of cotton fabrics even in 1914 (Abe 1990: 24). The rest of the cotton weaving was carried out in regional industrial districts, sanchi, most of which originated in the production area prosperous in the 1870 s or before. In these districts, clothiers and other manufacturers worked together in areas characterized by a highly concentrated presence of merchants dealing in products and materials. Even in 1905, as Table 6.3 shows, workers in "factory" production units employing 10 employees and more accounted for only $12 \%$ of the total number of workers in the entire industry. The statistics show that $30 \%$ of the workers were employed in workshops with less than 10 workers, and that $50 \%$ of the workers were in workshops organized under the putting-out system. ${ }^{3}$ In addition, the average number of workers in these workshops was less than two. The power loom ratio (the number of power looms divided by the total number of looms) remained as low as 16\% in 1914 (Abe 1989: 46).

We exemplify the development of these weaving districts by considering the Iruma region, which thrived at the turn of the twentieth century. ${ }^{4}$ The Iruma region, a southwestern part of Saitama prefecture adjacent to Tokyo, was a cotton-weaving district developed immediately after the Opening of the Ports. By the 1880s, the driving force was import of machine-made cotton yarn from overseas. This was followed by domestic cotton spinning mills, which replaced the expensive hand-spun yarn provided by nearby rural areas. Production initially developed under the Kaufsystem,

\footnotetext{
${ }^{3}$ Considering the working hours of weavers in each category, namely fulltime workers in the large factories and the seasonal side line weavers in the small workshops, the factories seem to have occupied larger proportion in terms of volume of the production than that of number of workers.

${ }^{4}$ The historical facts on Iruma weaving districts are obtained from Tanimoto (1998), Chaps. 6 and 7.
} 
where rural factors collected and purchased fabrics from weavers scattered around villages. At the end of the 1880s, however, the putting-out system, then a new way of organizing production in Japan, replaced the Kaufsystem. This was accompanied by an increase in the total volume of production. Putting-out continued to be the prevalent form of production organization until the mid-1920s. In this form, the direct producer, a Chin-ori (literally, a 'piece rate wage weaver') was supplied with dyed and warped yarn by the putting-out master, or clothier, and the producer wove fabrics according to a piece rate.

This transformation from the Kaufsystem to putting-out was triggered by competition in the market. Since cost reduction through the introduction of power looms was not a feasible choice because imported power looms were too expensive, it became vital for clothiers to enhance their competitive edge through improving the quality of their products. Under these circumstances, the putting-out system based on the supply of yarn served to improve the quality using standardized materials. Moreover, the clothier was able to provide wage-weavers with detailed market information, such as texture and design of fabrics, by supplying dyed, warped yarn, which played a pivotal role in the evaluation of product quality. The introduction and implementation of the putting-out system should then be seen as an adaptation strategy to emerging market conditions.

This case indicates that the newly introduced dispersed production system based on labour-intensive technology, weaving with a hand-loom, worked as a promoter of industrial development in modern Japan. It is also noticeable that this type of industrial growth was accompanied by a concentration of related traders within a relatively narrow area. The activities of clothiers were supported by merchants engaged in providing materials or selling products, dyers, and financial institutions, as well as trade associations and institutions of vocational education. Indeed, in Iruma, we can confirm the agglomeration of merchants and dyers in Tokorozawa town, a local centre in this area, together with the establishment of two trade associations and a local bank. The association also ran a small training school for dying skills in the 1900s. This was the formation of an industrial district, distinguished from a mere concentration of producers.

Around 1910, clothiers trying to introduce power looms emerged in certain weaving districts such as Izumi (Osaka prefecture), Chita (Aichi prefecture), Enshu (Shizuoka prefecture) (Abe 1989). Although this trend worked to transform the production form from putting-out to a factory system, it is worthwhile noticing that almost all power-looms introduced in these weaving districts were domestically manufactured machines whose prices were one third or less of imported British or North American power looms. Manufacturers near the leading weaving districts exploited low cost machines, substituting wooden staffs for metal parts to save expensive iron materials(Minami et al. 1982; Suzuki 1996). Since the relatively low price of domestic power looms lowered the barrier for clothiers to establish a machine equipped weaving factory, small scale factories proliferated in certain weaving districts from the 1910s onwards. Therefore, the introduction of domestic power-looms and establishment of small and medium sized factories in these cases, where the capital equipment rate was still lower than in full scale weaving factories, can be 
recognized as a continuous path of industrial development up to the 1930s, rather than a transformation from a labour-intensive to capital-intensive path.

In contrast, the Osaka Spinning Corporation was the first cotton spinning mill equipped with British spinning machines, comprising tens of thousands of spindles and employing several hundreds of spinners. Following its success, the proliferation of cotton spinning factories from the late 1880s onwards was apparently the capitalintensive path of industrialization, considering the amount of fixed capital required for machines and the facilities of a mill. In fact, almost all the spinning firms of this type adopted the newly introduced model of a joint stock company, rallying more than a hundred investors to cover the fixed cost. However, it is also worth emphasizing that the invested capital should have brought about high profits because the interest rate, or the price of capital, was relatively high in contemporary Japan, as is often the case in an industrializing economy. Continuous operation of factories was the key, and the assimilation of the technological knowledge by Japanese engineers, together with the provision of repair parts based on metal processing skills among domestic craftsmen, enabled the reduction of idle time caused by machine troubles (Nakaoka 2006, Chap. 5). On top of that, operation time was increased by adopting day and night shifts. Even though the night shift was costly because of the extra wage and the deterioration of workers' attentiveness, enhancing capital turnover was essential for higher return on equity (ROE). In other words, the capital-labour ratio of spinning mills tended to be lowered by increasing labour input through the double shift system (Takamura 1971; Sugihara 2013). It is also worth mentioning that the adoption of ring spindles from the late 1880s, which contributed to enhance total factor productivity of the spinning firms, was accompanied by the introduction of cotton mixing processes which required further labour inputs (Otsuka et al. 1988, Chap. 3). Thus, the labour-intensive nature can be discussed even in the case of exact transplantation of the Western factory system.

It is also noticeable that both sectors of the cotton industry, weaving and spinning, commonly depended on rural farming households as their source of workers. The order list of Takizawa Kumakichi, a leading putting-out master in Iruma, reveals that almost all the orders were directed to nearby farming villages, concentrating specifically in the middle layer of farming households there. In other words, piece weavers existed within the households that were inclined toward agriculture. In fact, the orders placed with the piece weavers by Takizawas showed strong and continuous seasonal fluctuations that clearly reflected the nature of this source of labour. Indeed, orders in May and June accounted for less than $10 \%$ of the yearly totals in almost all the years from 1896 to 1920 . It is not surprising that the seasonal fluctuations in time devoted to weaving were inversely related to the labour demand for farming within peasant households. The May-June period was harvest time in the region for wheat and tea, and peak season for silkworm breeding (for springtime).

In contrast, workers in cotton spinning mills came from the lower layer of farming households, whose cultivating lands were smaller than those in the middle layer. The well-known industrial report, Orimono Shokko Jijo (The Working Conditions of Weaving Workers), published by the central government in 1903, pointed out a distinction between the 'factory' pattern of labour organizations and that of the 
"peasant's side-line business". The report stated that "It is more beneficial for local women to weave fabrics according to a piece rate at home than to work for the factory that binds them for a long period of time. Therefore, in general, female workers at weaving factories are looked down upon in villages". 5 The report also recognized two separate sources of labour in the following remark: "Today, most of the local women employed at factories seem to come from financially-pressed families" (ditto). In fact, spinning mills organized a recruiting system seeking juvenile female workers with low opportunity costs, who were expected to exist in the lower layer of farming households scattered among rural villages that were usually far away from the location of the spinning mills in urban areas. As factory statistics ${ }^{6}$ reveal, the ages of female workers were highly concentrated under 25; in 1909, more than half were teenagers. The duration of their factory work was limited to their younger years, followed by re-inclusion in either farming or urban households as a household head's spouse, usually under the plural self-employment system. Although their working sites differed from home to factory, the underlying logic of labour provision was common, determined by the labour allocation strategy formed in each household.

Thus, the development of the cotton industry in late nineteenth to early twentieth century Japan strongly entailed the nature of labour-intensive industrialization being also effective for import substitution of cotton manufactured goods from Britain, British India, and other Western states. On the other hand, it is important to recall that the development of the cotton industry itself was a major factor in the growing trade imbalance. The key factor was importation of raw cotton from British India and the US, as already suggested in Table 6.2. The balance of payments for cotton related trade (the difference between the excess of exports in yarn and cloth and the excess of imports of raw cotton and cotton related machines) was apparently constantly negative, forming the major cause of the trade imbalance shown in Fig. 6.2 (Ushijima and Abe 1996). Although the cotton industry in those years could meet the growing domestic demand, it did not have a competitive edge in the rich market of Europe and North America. In this context, the significant role of export-oriented industries in financing the payments created by the growth of the import trade comes up. The next section discusses the dynamism of labour-intensive sectors in export-related industries.

\subsubsection{Dynamism of Export-Oriented Industries ${ }^{7}$}

It is well known that textiles constituted the largest part of Japan's export trade during the pre-World War II period. Raw silk (silk thread) was continuously Japan's single largest export until the early 1930s. The second largest export item shifted

\footnotetext{
${ }^{5}$ Cited from reprinted version; Noshomusho (1903/1998), vol. 2, p. 178.

${ }^{6}$ Kojotokeihyo (Statistical Tables of Factories) edited by Noshomusho (Ministry of Agriculture and Commerce).

${ }^{7}$ This section is mainly based on Tanimoto (2013a), 162-166.
} 
from silk cloth to cotton yarn in the early 1890s, and then to cotton cloth after World War I. Despite their significant role, textiles did not monopolize exports. The sum of various consumer goods (hereafter, miscellaneous goods) other than textiles contributed a considerable proportion of manufactured exports, although individual categories accounted for only small proportions. Indeed, by the 1930s, the combined export output of the following products made them joint contenders with cotton cloth or yarn for the second biggest export position: matches, knitted goods, hats, footwear, buttons, accessories, ceramics, glassware, enamel ironware, straw plaits, fancy mats, Western-style umbrellas, brushes, trunks, and toys. ${ }^{8}$

Apart from the volume, the changing patterns in the composition of exportoriented miscellaneous industries were also noteworthy. We can roughly distinguish three categories among the miscellaneous exports in Fig. 6.3, defined by the timing of their respective places in the export supply. Ceramics and lacquerware comprised the first category, with exports beginning soon after Japan's opening of ports in 1859. The second category comprised goods whose exports surged in the 1880s, including matches, trunks, straw plaits, and fancy mats, and accounted for a significant part of aggregate exports from the 1880 s to the 1900s. It is notable that the export of these goods commonly decreased sharply in the 1920s, and were unable to recover their position in the export trade throughout the interwar period. The third category comprised accessories, knitting goods, glassware, enamel ironware, and toys, exports of which increased gradually from the 1880 s, surged during World War I, and maintained an almost constant level in the 1920s. In the 1930s, there was a rapid increase in the export of some of these goods; for instance, toys, which we will focus on later.

Behind the shifting composition of these sales, there was an evolutionary process in production, such as changes in technology or location. The miscellaneous goods exported soon after the opening of the ports were characterized as traditional craft products, which attracted an overseas consumer market with a particular taste for Japanese style. Their production system, including technologies, skills, and the nature of workers, must have been inherited largely from the Tokugawa period. On the other hand, the straw plaits and fancy mats that made up $40 \%$ of miscellaneous goods exports during the late 19 th century were inferior goods to those available in overseas markets, such as carpets in the US. In addition, Japanese matches were regarded in South and East Asia as inferior goods to those imported from Europe. With regard to the system of production, a large portion of the output of straw plaits and fancy mats was produced as a side line by peasant households. Furthermore, even where the factory system had been adopted, it was established in the countryside and was based on handicraft technology with indigenous materials. In contrast, matches were produced mainly in urban settings, using imported technology. However, both types of production systems commonly involved a widely available source of labour-unskilled females - to produce relatively simple, uniform products. In this sense, they were typical labour-intensive industries but entirely different from the traditional crafts industry that employed skilled male workers.

\footnotetext{
${ }^{8}$ For the sources of historical information on each commodity, see the footnotes of Tanimoto (1995).
} 


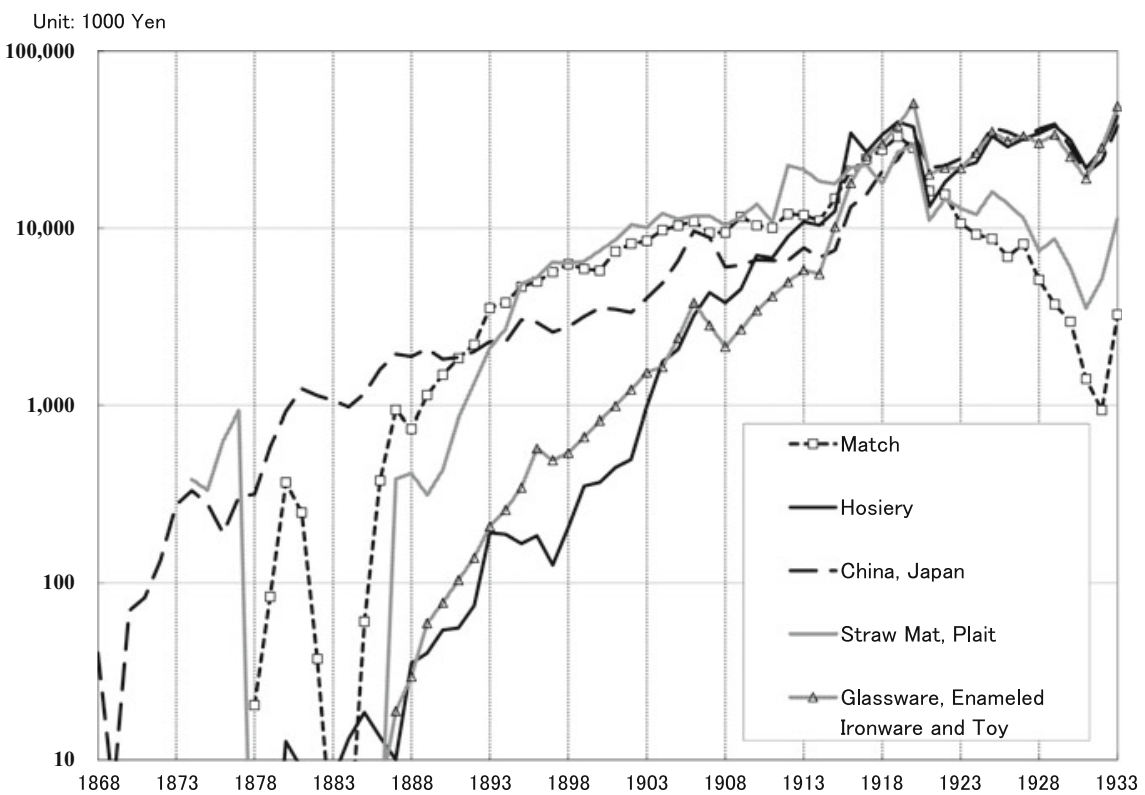

Fig. 6.3 Export of miscellaneous goods. Source Toyokeizai Shinposha (1935)

In contrast to these two categories, a distinct feature of the third category of export products was that they were 'new' items produced by 'transplanted' technology with 'new' materials, such as metals or chemical products, rubber, and celluloid. In addition, it is noteworthy that each individual industry in the third category manufactured various kinds of products with different uses or designs. Although the goods continued to be inferior in quality, their manufacturers were required not only to supply low-priced goods but also to respond to consumer tastes. In other words, these industries had to be able to acquire market information and hold 'skilled' labour, broadly defined, to reflect market information in the products.

Table 6.4 shows this direction of transformation from another angle. The table compares the export markets of industries with significant shares of total exports in 1937. The export markets are divided into four areas. A includes 'Manchuria' in northeast China and the 'Kwantung Leased Territory', also in China. B includes the rest of Asia, excluding the areas in the Japanese Empire, such as Korea and Taiwan. $\mathrm{C}$ includes Central and South America, Africa, Oceania, and the Middle East. D includes Europe and North America. For manufactured products, barriers to entry appeared to be highest in the case of markets in the industrialized countries in D. On the contrary, barriers to entry could have been lowered by Japanese political influence in area A. Barriers to entry in areas B and C were in between those two. In fact, machine-manufacturing industries, which were technologically backward compared with those in the Western industrialized countries of those years, mostly limited their market to area A. By contrast, almost all raw silk was exported to 
Table 6.4 Japan's export trade in 1937

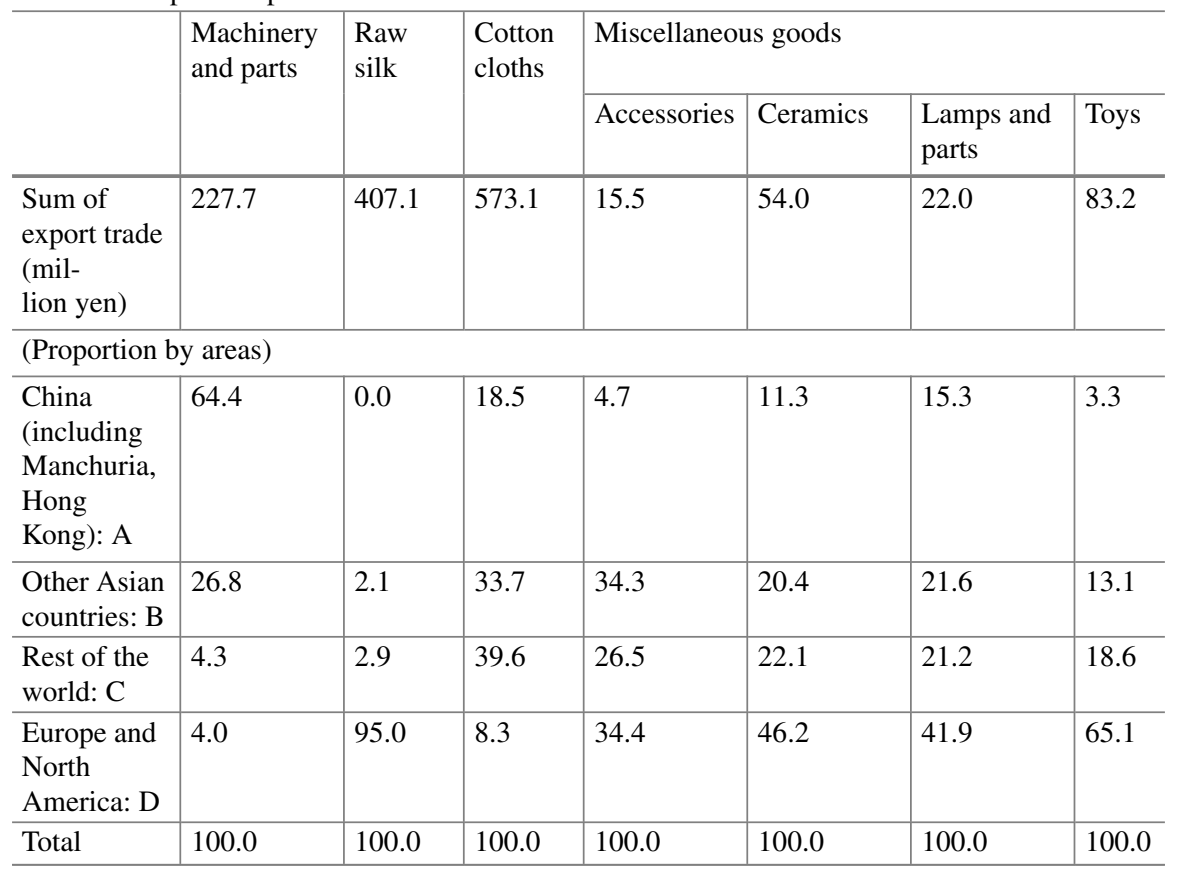

Source Okrasho ed. Dai-Nihon Boeki Nenpyo

area D, particularly to the US, based on the tight ties between the weaving and knitting industries in that country, and their supplier of intermediate goods in Japan. Meanwhile, cotton cloth made up the largest volume of consumer goods exports. Less than $10 \%$ of cotton cloth exports were to area D. In contrast with all these categories of exports, a distinct feature of the miscellaneous goods was the relatively high proportion of exports to area D. In addition, this area was the largest market for toys, accessories, ceramics, and table lamps, and these goods almost matched the items included in the abovementioned third export category.

Therefore, the export-oriented development of Japan's miscellaneous industries during the interwar period was made possible by penetrating the markets of highincome countries in the face of competition from within those industrialized countries. This was one of the industrial frontiers for the Japanese economy in those years. The case of the toy industry discussed in the next section exemplifies this dynamism well. 


\subsubsection{The Development of Japan's Toy Export ${ }^{9}$}

Toy exports increased continuously from the turn of the 20th century, declined after the Japan-Russo War, and soared from World War I to the period of the post-war boom. Exports dropped sharply in 1920 and stagnated during the first half of the 1920 s, followed by a certain level of recovery in the latter half of the decade. Although there was a negative effect from the Great Depression around 1930, toy exports rose from 1932 up to 1938, when the war economy placed great limitations on the manufacture of 'non-necessities'. Comparing these export statistics to those of import and production, we can identify the distinct feature of toy manufacturing. First, the export-production ratio exceeded $100 \%$ in many years. This seemingly irrational percentage can be understood partly by considering the limits of the original statistics, such as coverage of the production data. ${ }^{10}$ Still, it is realistic to assume that most toy products were manufactured for overseas markets. Second, it is important to mention that there were very few imports of toys from the late nineteenth century. Third, the breakdown of the materials used in exported toys also reveals that more than half were made of rubber, celluloid, and tin from 1920 onwards.

These facts suggest an intriguing argument in considering the relationship between trade patterns and industrial development. The development of the toy industry had been consistently led by the growth of export trade through the manufacture of newly developed items made from materials originating in foreign 'advanced' countries with very small importation of the original goods. Thus, toy manufacturing did not follow the typical 'flying geese model', where development patterns are a series of steps from importation to import substitution, and from saturation of domestic markets to exportation (Yamazawa 1984). It was the demand from overseas, not the domestic market, that formed the starting point for the toy industry. This pattern differs not only from the cotton industry, which fitted the flying geese model well by exemplifying efforts for import substitution discussed in the previous section, but also from the export-oriented raw silk industry, which exemplified the changing patterns of indigenous industries that had long been dependent on the domestic market, and started exporting after the opening of the ports in 1859 .

Although Japanese toys occupied the US import market during World War I in the absence of Germany, a dominant provider to the international toy market, the share of Japanese toys in the US market fell drastically throughout the 1920s. These trends clearly reveal the lack of global competitiveness of Japanese toy manufacturing at that time. However, the situation changed from the late 1920s, when the share of Japanese toys in the US and UK markets started to rise gradually, and even soared in the 1930s, displacing German toys. It is noteworthy that the trend started to change before 1932, when the depreciation of the yen began to provide favourable conditions for export.

\footnotetext{
${ }^{9}$ The discussion in this section draws on Tanimoto (2017). For the sources of the following descriptions, see the footnotes and references in Tanimoto (2007).

${ }^{10}$ Although trade statistics covers, in theory, all exported toys, the most consistent statistics for production, Kojotokeihyo (Statistical Tables of Factories), covered factories and workshops employing five or more employees only.
} 


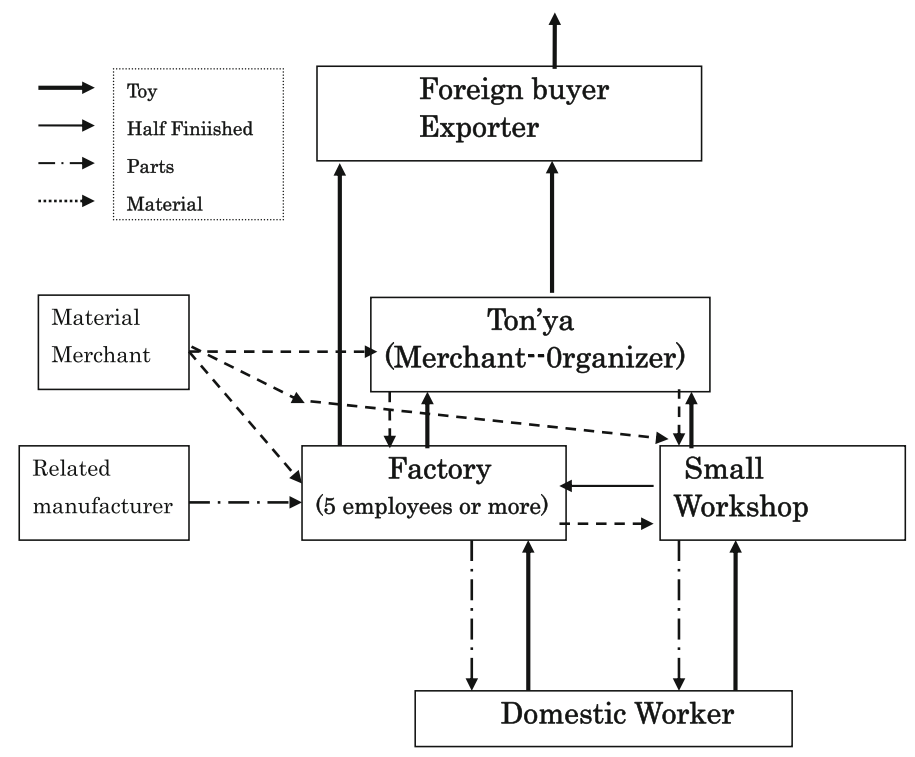

Fig. 6.4 Production organization of the toy manufacturing industry in Tokyo

This fact suggests that the competitive edge of Japanese toys rested not only on the deterioration of price, but also on improvement in the quality of the products. In fact, the foreign trade division of Shokosho (the Ministry of Commerce and Industry) stated in its trade reports ${ }^{11}$ that the toy industry went beyond the emulation stage, and acquired the ability to create innovative designs. The focal point is the fact that this improvement was carried out under the context of labour-intensive industrialization.

Figure 6.4 illustrates the production organization of the toy manufacturing industry. The merchant organizers were located between manufacturing workshops and the export markets, connecting manufacturers to distributors. They often related to the production process by coordinating workshops for manufacturers, who took charge of the partial processes. It is notable that the number of non-factory workshops far exceeded the number of factories that employed more than four workers. The workforce was composed of employers, family workers, 'apprentices', and adult labourers. Based on their role in the organization of production, there are two categories of manufacturers: core manufacturers producing finished goods, and rather small workshops performing partial processes. The former tended to be associated with factories; however, it was not unusual for non-factory workshops to provide finished goods to wholesalers. In contrast, the work assigned to domestic workers was limited to partial processing or simple assembly, and even small workshops placed orders with domestic workers. In addition, the gender composition of the workforce differed by type of workers, as most domestic workers were female.

\footnotetext{
${ }^{11}$ Honpo Gaikokuboekigaikyo (The overview of the foreign trade of Japan) edited by Shokosho.
} 
The origin of the competitive edge of the toy manufacturing industry lay in this organizational character. In fact, it was usual to economize labour cost by subcontracting to domestic workers. The employment of juvenile workers as 'apprentices' might have also had a similar effect on the labour cost of small-scale workshops. However, toys were not the kind of goods whose demand was determined mostly by price. They were subject to fashion, and supplier had to match or even develop the taste of consumers in order to increase their sales. In this context, it is rather notable that each category of actor-merchant organizer, factory workshop, and non-factory workshop-included firms that had the ability to design the goods. The records of the registration of designs and devices, held either at the National Patent Office or by the trade association of toy manufacturing, reveal that firms in each of these three sometimes succeeded in registering theirs ideas. In other words, several small workshops, as well as merchant organizers and "factories", were capable of creating the original models of products. Therefore, we should not simply assume that the relationship between merchant organizer and manufacturer, or between consigner and consignee among manufacturers, was complementary or exploited the division of labour. While the influential merchant organizer vertically coordinated the production process under its own control, there were manufacturers, including non-factory workshops, who designed and produced finished goods on their own accounts. These manufacturers sometimes held relatively strong positions in the negotiation processes with merchant organizers. The relationship between merchant organizers and manufacturers included competition on the same grounds, as well as transactions based on the vertical division of labour. Thus, the production organization of the toy manufacturing industry was by no means static for the traders, and this competitive nature among traders was maintained through vigorous new entries that resulted from the establishment of independent workshops, as a product of the life course of the workers.

In addition to the endogenous factor of the organization, we can point out some other external factors that support the competitive edge of the industry. One of the conspicuous features of the toy manufacturing industry was the agglomeration of the traders within a relatively small area. For example, in Tokyo, the centre of toy production from the 1920s onwards, the location of more than 40 merchant organizers in 1933 was almost entirely limited to only two blocks in the commercial area. Metal toy manufacturers were concentrated in three blocks, with 39 in one block (Umayabashi). The situation was almost the same for celluloid toy manufacturers. The highly concentrated location of traders suggests the positive effects of agglomeration, reminding us of the arguments of Alfred Marshall and others regarding the effects of external economies in industrial clusters (Marshall 1920). For instance, for merchant organizers, proximity to other traders engaged in the same industry might have increased their opportunities to acquire market information, which was indispensable for the sale of fashionable goods. The agglomeration also facilitated development of the division of labour among traders, which might have increased the productivity of the industry. 
Moreover, it was noticeable that traders located within each cluster were not limited to toy traders. In fact, as the directory of celluloid traders of 1939 indicates, it is better to say that celluloid toy workshops were located within the agglomeration of traders of various celluloid goods. This appears to have been true of traders in metal or rubber toys as well. These facts suggest that the traders might have moved in among industries that used the same material. Indeed, by matching the trade directories of different years, we can confirm that several celluloid toy manufacturers changed their product to other celluloid goods during the course of time and vice versa. This flexibility among traders appears to have relieved the blows of market fluctuations. Although this buffer function was probably limited, as market trends of the industries would not have been inversely correlated to compensate for the slump of the other industry, it might have provided more opportunities to survive, at least for traders with a relatively high ability to respond to the unstable economic environment.

Meanwhile, the coexistence of related industries in the same area was important for the toy traders as well. Mould producers were a typical example. In order to acquire the fruits of product innovation, it was vital for traders to possess the moulds. However, a relatively high level of skills was required to produce the moulds, and it was rather difficult for the traders, particularly small workshops, to internalize this process. In this situation, the mould 'factories' generated within the agglomeration of metal-processing workshops near the agglomeration of toy traders, or the mould-processing workshops whose locations overlapped with those of celluloid toy manufacturers, played an important role in actualizing the originally generated ideas as real products. Similar roles were played in the areas of businesses that required relatively high skills, such as manufacturing springs and gears, and printing tin plates. The agglomeration of related industries provided complementary factors that were indispensable to the development of the dispersed production organization based on small workshops. Thus, the competitive edge of toy production was largely rooted in its location in urban settings, specifically the metropolis of Tokyo. In fact, as is seen in the following section, Tokyo became the largest industrial city comprising the agglomeration of various kinds of small scale workshops in the interwar period.

\subsubsection{The Structure of Small-Scale Industries in Interwar Tokyo}

Table 6.5 is based on data extracted from an industrial census conducted by the Tokyo Municipal Office in 1932 (Kogyo Chosa-sho). ${ }^{12}$ It indicates the proportion of small workshops run on a self-employment basis in the manufacturing sector. In light of the number and composition of workers, workshops with 2,000-4,999 yen of capital appear to be the upper threshold for self-employment-based workshops. These workshops comprised $87.7 \%$ of all workshops and factories, and employed

\footnotetext{
${ }^{12}$ The following discussion on the structure of small-scale industries is a summary of Tanimoto (2013a), 154-162.
} 
$49.3 \%$ of all workers. It is apparent that family workers, including employers, played significant roles in the workforce. The high proportion of 'apprentices' recorded in the census is also striking. There were more 'apprentices' than 'labourers'. This implies that these workshops depended greatly on workers other than 'labourers', who were the main work force of the large factories. On the other hand, we can estimate by the industrial census that more than half of the workshops belonging to the layer of capital of 2,000-4,999 yen were equipped with prime movers. Although the difference in per capita fixed capital according to scale was clear, small workshops were not simple equivalents of the traditional handicraft manufacturing industry. Thus, not a few small workshops were engaged in processing newly introduced materials with relatively small fixed capital; in other words, resting their production more on labour than on capital when compared with large factories. In this sense, we can certainly regard small workshops as being labour-intensive. How then did labour-intensive workshops manage to survive or even develop in the face of the competition with capital-intensive factories? To tackle this question, let us focus on the nature of their workforce.

As mentioned above, small workshops had three types of workers: 'family workers', 'labourers', and 'apprentices'. With respect to gender, we should point out the high proportion of male workers, accounting for more than $70 \%$ in each type. This gender bias contrasts to that of the textile industries in both types of factories, as well as in side-line jobs, and suggests the different nature of the workforce in urban small-scale industries. On the other hand, it is noteworthy that the age range clearly differed according to the composition of the workforce. The number of 'apprentices', which is the highest among the three main categories of workers, was greatest among teenage workers, accounting for two-thirds of the workers in the same age group. In contrast, 'family workers', including employers, accounted for more than $80 \%$ of the workers over the age of 30 . In between were the 'labourers', who accounted for the highest number of workers in their twenties, but the smallest number of workers overall. These facts enable us to suggest that a strong tendency existed to change one's industrial status from that of an 'apprentice' to 'labourer', and from 'labourer' to 'family worker (employer)'. The latter change implies the existing intention among employees to be independent by establishing their own workshops, and the former suggests the importance of skill formation to become a full-fledged worker.

According to an industrial survey carried out in 1936 in Tokyo, ${ }^{13}$ more than $70 \%$ of the manufacturers across 26 trades replied that they required more than two years of training. In the case of six of these trades, more than $40 \%$ of the manufacturers claimed that a period of five years of training was necessary. This is in sharp contrast to the case of "domestic workers" in the same survey. Half of the domestic workers could work without any training, and another quarter could work with training of less than one month. These observations make it clear that a workforce with a certain level of skill was required for the small workshops, and this attribute of the workforce provided the foundation for an 'apprentice' being distinguished from a mere 'juvenile labourer'. We do not possess any concrete evidence to confirm that

${ }^{13}$ Tokyo Municipal Office ed. (1937). 


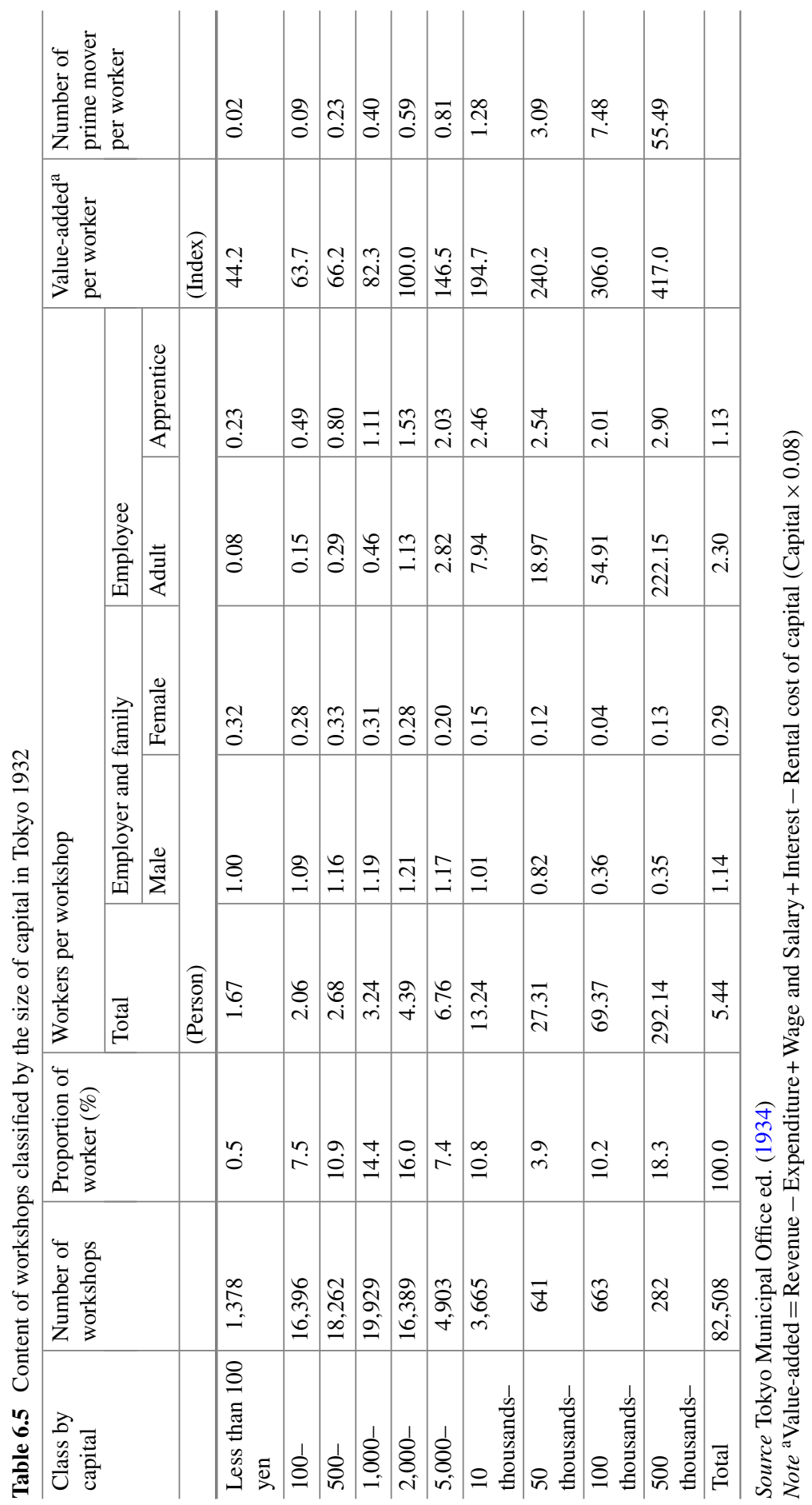


an institutionalized apprenticeship with a formal training period or restriction of job entry was effectively operating in these trades at that time. However, we can probably assume that substantial needs existed for the training of workers, and it was natural that some system, though not a formal institution, emerged to meet the demand. The fact that the word 'apprentice' was commonly used in the official investigation might be evidence that one existed.

An investigation of the "apprentices", which was conducted around 1938 and based on 3,768 samples, including 2,990 males, supports this speculation. ${ }^{14}$ The investigation reveals that more than half of the male juveniles intended to undergo training at the workplace. Judging from the data on age, working period, and the experience of changing jobs, it appears that a majority of the male 'apprentices' had worked at the same workshop for at least two years. These findings are almost consistent with the data on the training period mentioned above. On the other hand, as we see in the following part of this section, the low wages of these juvenile workers were profitable for the employers. The employers also needed 'apprentices' for cheap labour. Though we do not possess any further information for analysing the equilibrium between the cost of training and low wages, we can probably assume that being trained as an 'apprentice' during their teens, albeit informally, was built into the early stage of the life course of the workers in the small-scale industries.

What was the outcome of these small workshops? Table 6.5 presents the average value-added labour productivity of the workshops in each layer. Since income data tended to be underreported for fear of tax liability, the calculated value-added may be understated. Despite this, great differences between the layers in value-added productivity are apparent. For example, the average productivity of the workshops (or rather, factories) with the largest capital of 500 thousand yen or more, was recorded as four times higher than those with capital of 2,000-4,999 yen. Labour productivity increased in accordance with the increase in capital employed. Therefore, the higher physical productivity of labour achieved by utilizing machines or prime movers might account for most of the productivity differential. In other words, the market value of the products of the small-scale workshops could not compensate fully for their relatively low physical productivity. Although some products might have realized higher market value based on unique technology or skills, in general, the smallscale workshops should be recognized as an industrial sector with relatively low productivity.

However, the difference in productivity was not the decisive factor undermining the competitiveness of the small workshops. Their earnings, after deduction of costs including wages, can be caluculated from this industrial census. It is clear that scale greatly influenced earnings, since the earnings of the small workshops were significantly below the wages of labourers employed in the large-scale factories. However, it should be noted that the earnings of workshops capitalized at 2,000-4,999 yen or more apparently exceeded the highest wages of the labourers employed. Even the earnings of the next layer down, with capital of 1,000-1,999 yen, almost equalled the second highest wage level of factory labourers. This level of earnings might not

${ }^{14}$ Tokyo Prefectural Office (1939). 
have discouraged employed labourers from establishing their own workshops. In fact, the wages of employees in workshops whose capital were under 10,000 yen, and which employed more than half of the total employees, could not reach the level of earnings mentioned above. This implied that employees with lower wages had no chance of increasing their income as long as they remained employees, given the low possibility for workers to move from small workshops to large ones. Therefore, establishing one's own workshop must have appeared as a promising option, although it involved considerable risks. The differential wages according to the scale of workshops, which also reflected small workshops' use of juvenile workers as 'apprentices' (as mentioned above), enabled small workshops to earn a certain amount, although their value-added labour productivity was considerably lower than that of largescale factories. On the other hand, this motivated adult labourers to establish their own workshops.

In summary, we may assume a particular life course of workers employed in urban industries. Teenaged males worked in small workshops, undergoing on-thejob training and acquiring a certain level of skills. After being employed in their twenties as adult labourers, some of them might succeed, possibly with some luck, in establishing their own workshops. It was this shared perspective of a certain life course that enabled the skill formation and low wage compatibility in urban industrial settings.

\subsubsection{Prospects to the Post-war Development}

Thus, the development of urban small-scale industries represented the dynamic nature of labour-intensive industrialization in pre-war Japan. Specifically, exportoriented manufacturing sectors such as toy making showed distinctive growth in the 1930s, driving the relatively faster recovery of the Japanese economy from the Great Depression.

On the other hand, it is plausible that the "success" of these export-oriented industries intrinsically entailed tension between Japan and its trading partners, or among trade rivals. In fact, it is well known that the expansion of cotton textiles exports to South and Southeast Asia in the 1930s resulted in a bilateral trade negotiation between Japan and Britain, British India and the Netherlands, the colony and the suzerain states. Regarding urban toys, the United States imposed more than $100 \%$ duties in 1930 (converted to an ad valorem tax). Even Britain, which had advocated a free trade regime, imposed $15-25 \%$ ad valorem duties on Japanese toys in the 1930s. ${ }^{15}$ Furthermore, the progress of the controlled economy following the outbreak of Sino-Japan war from 1937 onwards suppressed the manufacturing sectors producing consuming goods irrelevant to military needs. In fact, the production of export-oriented goods such as toys, textile goods and ceramics deteriorated significantly under the war-economy from the late 1930s to 1945.

\footnotetext{
${ }^{15}$ Regarding duties imposed on Japan's exported toys, see Tanimoto (2013b), 61.
} 


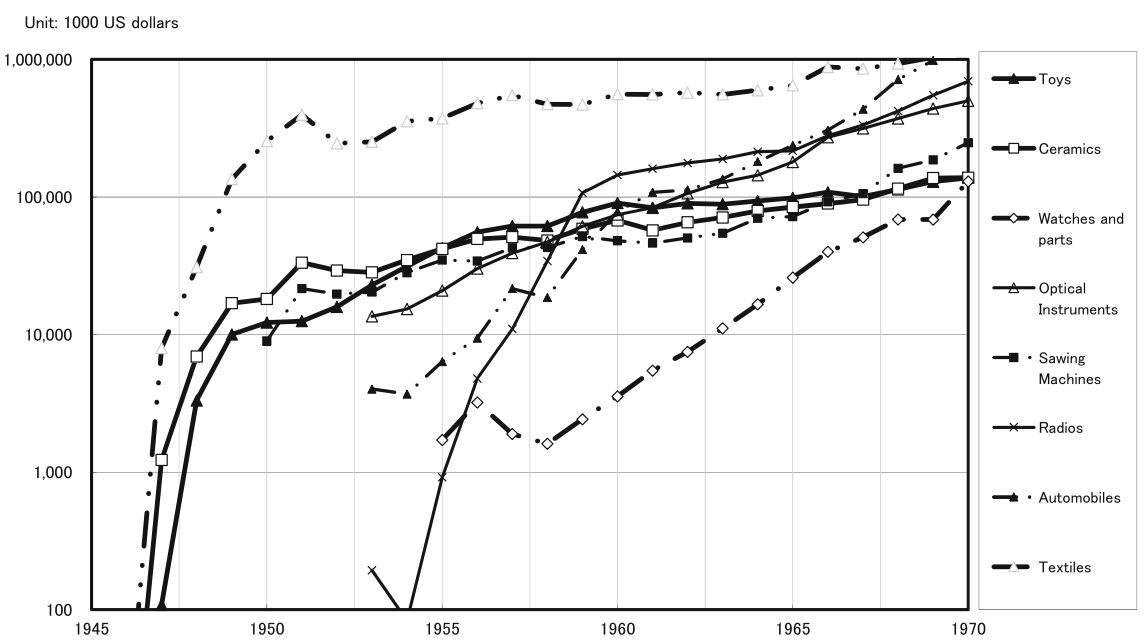

Fig. 6.5 Japan's export trades after World War II. Source Tsushosangyoseisakushi Hensaniinkai (1992)

Despite resulting in the disastrous situation, however, it is still important to notice the fact that the development of urban-based export-oriented industries during the interwar period can be regarded as one of the industrial frontiers for the Japanese economy, as mentioned in the previous section. The distinct feature was that their markets primarily targeted the demands of high-income countries, where they won a competition with their counterparts in those industrialized countries. It was not just the achievement of industrialization in the pre-war stage, but it also appears to have been the forerunner of industries exporting finished consumer products to Western industrialized countries after World War II.

According to Fig. 6.5, cotton textile goods led export trade soon after the end of WWII, followed by toys, ceramics, optical instruments (binoculars and cameras), and sewing machines as the second group. It is noticeable that the continuous export trends, such as toys and ceramics from the pre-war period, overlapped those of the latter two that newly emerged after WWII. Furthermore, this trend can be extended to the exportation of radios and watches in the 1960s by creating a category of "light machines", ${ }^{16}$ from binoculars to sewing machines to radios. ${ }^{17}$ In fact, these products can be categorized as finished goods targeting markets in high-income states, despite the differences in technological basis. Table 6.6 clearly shows that these finished goods, included under the headings of "machines" and "others" in this table, had largely helped compensate for the decline in raw silk in export trade to the US, which had formed more than $80 \%$ of Japan's exports to the US in 1929, but sharply deteriorated after the Great Depression. Recalling the growing weight of export trade

\footnotetext{
${ }^{16}$ Sawai and Tanimoto (2016) explicitly touches on, though briefly, the role of "light machine" in post war Japan (p. 386).

${ }^{17}$ Sawai (2013) discussed the development of Japan's export of binoculars from the 1950s to 1960s.
} 
Table 6.6 Proportion of commodities in export to US

\begin{tabular}{c|l|l|l}
\hline & 1937 & 1960 & 1965 \\
\hline Food & $\mathbf{8 . 2}$ & $\mathbf{5 . 6}$ & $\mathbf{2 . 9}$ \\
\hline Textile & $\mathbf{6 6 . 1}$ & $\mathbf{2 6 . 7}$ & $\mathbf{1 8 . 4}$ \\
\hline Raw silk & 51.2 & & \\
\hline Clothing & & 8.4 & 5.8 \\
\hline Chemical goods & $\mathbf{6 . 1}$ & $\mathbf{1 . 4}$ & $\mathbf{1 . 7}$ \\
\hline $\begin{array}{c}\text { Nonferrous metals, } \\
\text { mineral goods }\end{array}$ & $\mathbf{3 . 8}$ & $\mathbf{5 . 4}$ & $\mathbf{3 . 9}$ \\
\hline Potteries & 3.1 & 3.6 & \\
\hline Metal and metal goods & $\mathbf{1 . 1}$ & $\mathbf{1 4 . 2}$ & 1.6 \\
\hline Steel & 0.0 & 5.6 & $\mathbf{2 5 . 7}$ \\
\hline Machinery & $\mathbf{0 . 3}$ & $\mathbf{1 4 . 4}$ & 17.3 \\
\hline Sewing machines & 0.0 & 2.0 & $\mathbf{2 6 . 1}$ \\
\hline Radio & 0.0 & 5.7 & 1.3 \\
\hline Others & $\mathbf{1 4 . 4}$ & $\mathbf{3 2 . 3}$ & 3.8 \\
\hline Toys & 2.6 & 5.2 & $\mathbf{2 1 . 4}$ \\
\hline Optical instruments & 0.1 & 3.0 & 1.8 \\
\hline Plywood & 0.0 & 3.7 & 3.3 \\
\hline Total & 100.0 & 100.0 & 1.8 \\
\hline Source Okuras & & 100.0 \\
\hline
\end{tabular}

Source Okurasho ed. Dai-Nihon Boeki Nenpyo and Gaikoku Boeki Gaikyo

to the US after WWII, we may recognize that the production of these finished goods embodied the direction of the industrialization that led post-war Japan's economic development. In that sense, the development of small scale urban-based industries, such as toys, was one of the distinct aspects of labour-intensive industrialization in pre-war Japan and continued through post-war Japan's rapid economic growth.

\subsection{Concluding Remarks}

Japan's pre-war economic development can be seen as the case of an emerging state, trying to catch up to the "advanced" west after the Opening of the Ports and Meiji Restoration. The concept of labour-intensive industrialization worked well to explain its development, specifically by considering the changing role of labour-intensive sectors. From the late nineteenth to early twentieth century, the rural-based dispersed cotton weaving industry played a significant role in substituting for imported cotton textiles typically factory-manufactured in "industrialized" states. The success of the transplantation of factory-based cotton spinning should also be explained, if partly, by the reduction in the capital-labour ratio through adoption of a double-shift system and a cotton-mixing technic required for introducing ring spindles. The invention 
of narrow-sized power-looms made from a mixture of iron and wood, saving the expensive iron parts, was another example of the capital-saving way of assimilating imported technologies.

On the other hand, the development of import-substitutive industries, such as cotton related manufacturing, had to be complemented by export-oriented industries to relax the trade imbalance caused by the increase in imports, consisting of raw materials and, in some cases, advanced machines; in the case of the cotton industry, these were raw cotton and spinning machines. The urban-based, export-oriented small-scale industries deserve special attention in this regard. Their growth in the interwar period supported the expansion of export trade, particularly in the 1930s, compensating for the decline of raw silk, which was previously the major component of exports. They based the labour force on male workers with a certain level of skills acquired by being a kind of apprentice when they were young. The potential possibilities of moving from employees to employers through the establishment of their own workshops encouraged juvenile workers to invest in skill formation, and made them tolerate relatively low wage levels, both supporting the competitiveness in the world market. Thus, the composition of the workforce was distinctively different from the textile industry, which had been the major labour-intensive industry up to the interwar period, endowing Japan's labour-intensive industrialization with its dynamic nature.

In fact, it was in a new wave of export trade targeting mainly the demands of high-income countries where they won a competition with their counterparts in those industrialized countries. On one hand, this achievement might have resulted in causing, at least partly, a rural-urban divide in domestic settings, ${ }^{18}$ and trade conflict in an international sphere. This can be seen as comparable to the concept of the "middle income trap" in the contemporary emerging states argument, since Japan's economy became stagnant and even deteriorated from the late 1930s to 1940s because of the war economy. At the same time, the achievement of the pre-war stage can be regarded as the basis for industries exporting finished consumer products to Western industrialized countries after World War II, the emergence of new competitive products from binoculars to watches, and probably to home electronics appliance and transportation machines. In this sense, the perspective of labour-intensive industrialization is open to the post-war rapid economic growth, the last stage of the Japanese economy as an emerging state.

\footnotetext{
${ }^{18}$ There are quite a few discussions on this issue in diverse streams of literature from pre-war period to the present. For brief overviewing of the discussions underlying the literature, see Minami et al. (1998).
} 


\section{References}

Abe, T. (1989). Nihon niokeru Sanchi Menorimonogyo no Tenkai (The development of cotton weaving districts in Japan). Tokyo: Tokyodaigaku Shuppankai.

Abe, T. (1990). Menkogyo (Cotton manufacturing industry). In S. Nishikawa \& T. Abe (Eds.), Nihonkeizaishi 4 Sangyoka no Jidai Jo. Iwanami Shoten: Tokyo.

Marshall, A. (1920). Principles of Economics (8th ed.). London: Macmillan.

Minami, R., Ishii, T., \& Makino, F. (1982). Gijyutsu fukyu no shojoken: rikishokki no baai (The conditions of the diffusion of technology: In cases of power looms). Keizaikenkyu, Hitotsubashi University, 33(4), 334-359.

Minami, R., Nakamura, M., \& Nishizawa, T. (Eds.). (1998). Demokurashi no Houkai to Saisei: Gakusaitekisekkin (The collapse and restoration of democracy: An inter-disciplinary approach). Tokyo: Nihonkeizai Hyoronsha.

Nakamura, S. (1968). Meijiishin no Kisokozo: Nihon Shihonshugi Keisei no Kiten (Basic structure of Meiji restoration: The starting point of the formation of the Japanese capitalism). Tokyo: Miraisha.

Nakamura, T. (1971/1983). Senzenki Nihon Keizaiseicho no Bunseki, Tokyo, Iwanami Shoten translated into Economic Growth in Pre-war Japan. New Haven: Yale University Press.

Nakaoka, T. (2006). Nihon Kindaigijyutsu no Keisei: "Dento" to "Kindai" no Dainamizumu (The formation of the modern technology in Japan: Dynamism of "tradition" and "modernity"). Tokyo: Asahi Shinbunsha.

Noshomusho. (1903/1998). Shokkojijo reprinted by Iwanami Shoten.

Ohkawa, K. et al. (1974). Choki Keizaitokei 1 Kokuminshotoku (Estimates of long-term economic statistics of Japan since 1868, vol. 1 National income). Tokyo: Toyokeizai Shinposha.

Otsuka, K., Ranis, G., \& Saxonhouse, G. (1988). Comparative technology choice in development: The Indian and Japanese cotton textile industries. London: Macmillan Press.

Sawai, M. (2013). 1950, 60 nendai no sogankyo kogyo to amerika shijo (The binocular industry in the 1950s \& the 1960s and the US market). Osakadaigaku Keizaigaku, 63(1), 151-178.

Sawai, M., \& Tanimoto, M. (2016). Nihonkeizaihi: Kinsei kara Gendai made (The economic history of Japan: From the early modern era to the present). Tokyo: Yuhikaku.

Sugihara, K. (2013). Labour-intensive industrialization in global history: An interpretation of East Asian experience. In G. Austin \& K. Sugihara (Eds.), Labour-intensive industrialization in global history (pp. 20-65). London: Routledge.

Suzuki, J. (1996). Meiji no Kikai Kogyo: Sono Seisei to Tenkai (Machinery industry in Meiji: Its formation and development). Kyoto: Mineruva Shobo.

Takamura, N. (1971). Nihon Bosekigyoshi Josetsu Jo (The introduction to the history of cotton spinning industry in Japan, vol. 1). Tokyo: Hanawa Shobo.

Tamura, H. (2004). Fasshon no Shakaikeizaishi (The socio-economic history of fashion). Tokyo: Nihonkeizai Hyoronsha.

Tanimoto, M. (1995). Kindai nihon niokeru 'zairaiteki' keizaihatten to kogyoka: shonin, chushokigyo, meiboka (Industrialization and the "indigenous" economic development: Merchant, small and medium size enterprises and notables). Rekisihyoron, 539, 92-109.

Tanimoto, M. (1998). Nihon niokeru Zairaiteki Keizaihatten to Orimonogyo: Shijokeisei to Kazokukeizai (The indigenous economic development and the weaving industry: Market formation and household economy). Nagoya: Nagoyadaigaku Shuppankai.

Tanimoto, M. (2006). The role of tradition in Japan's industrialization: Another path to industrialization. In M. Tanimoto (Ed.), The role of tradition in Japan's industrialization (pp. 3-44). Oxford and New York: Oxford University Press.

Tanimoto, M. (2007). The development of dispersed production organization in the interwar period: The case of the Japanese toy industry. In T. Okazaki (Ed.), Production organization in Japanese economic development (pp. 167-208). London and New York: Routledge. 
Tanimoto, M. (2009). Cotton and the peasant economy: Foreign fibre in early modern Japan. In G. Riello \& P. Prasannan (Eds.), The spinning world: A global history of cotton textile 1200-1850 (pp. 367-385). Oxford and New York: Oxford University Press.

Tanimoto, M. (2013a). From peasant economy to urban agglomeration: The transformation of labour-intensive industrialization in modern Japan. In G. Austin \& K. Sugihara (Eds.), Labourintensive industrialization in global history (pp. 144-175). London: Routledge.

Tanimoto, M. (2013b). Senkanki nihon no chushoshokogyo to kokusai shijo: Gangu yushutsu wo jirei toshite (Japanese small-scale manufacturing in the international market: Export-oriented toy business in interwar period). Osakadaigaku Keizaigaku, 63(1), 51-73.

Tanimoto, M. (2017). From emulation to innovation: Japanese toy export to high-income countries before World War II. In K. Furuta \& L. Grove (Eds.), Imitation, counterfeiting and the quality of goods in modern Asian history (pp. 225-243). Singapore: Springer.

Tokyo Municipal Office (Ed.). (1934). Kogyo Chosa-sho (Census of Industry).

Tokyo Municipal Office (Ed.). (1937). Tonyasei Shokogyo Chosa (Survey on small manufacturing and processing workshops under the putting-out system).

Tokyo Prefectural Office (Ed.). (1939). Chushokigyo no Keiei Jijo to Totei no Rodo Jijo (An investigation on the management of small and medium firms and the working conditions of apprentices).

Toyokeizai Shinposha (Ed.). (1935). Nihon Boeki Seiran (Statistical book on Japan's oversea trade). Tokyo: Toyokeizai Shinposha.

Tsushosangyoseisakushi Hensaniinkai (Ed.). (1992). Tsushosangyoseisakushi 16 Tokei Nenpyo hen (The history of trade and industrial policy vol. 16 Statistics and chronological tables). Tokyo: Tsushosangyo Chosakai.

Umemura, M., et al. (1988). Choki Keizaitokei 14 Rodoryoku (Estimates of long-term economic statistics of Japan since 1868, vol. 2 Labour force). Tokyo: Toyokeizai Shinposha.

Ushijima, T., \& Abe, T. (1996). Mengyo (Cotton industry). In S. Nishikawa, K. Odaka, \& O. Saito (Eds.), Nihon Keizai no 200 nen. Tokyo: Nihon Hyoronsha.

Yamazawa, I. (1984). Nihon no Keizaihatten to Kokusaibungyo (Japan's economic development under the international division of labor). Tokyo: Toyokeizai Shinposha.

Yamazawa, I., \& Yamamoto, Y. (1979). Choki Keizaitokei 2 Boeki to Kokusaishushi (Estimates of long-term economic statistics of Japan since 1868, vol. 14 Foreign trade and balance of payments). Tokyo: Toyokeizai Shinposha.

Open Access This chapter is licensed under the terms of the Creative Commons AttributionNonCommercial-NoDerivatives 4.0 International License (http://creativecommons.org/licenses/bync-nd/4.0/), which permits any noncommercial use, sharing, distribution and reproduction in any medium or format, as long as you give appropriate credit to the original author(s) and the source, provide a link to the Creative Commons licence and indicate if you modified the licensed material. You do not have permission under this licence to share adapted material derived from this chapter or parts of it.

The images or other third party material in this chapter are included in the chapter's Creative Commons licence, unless indicated otherwise in a credit line to the material. If material is not included in the chapter's Creative Commons licence and your intended use is not permitted by statutory regulation or exceeds the permitted use, you will need to obtain permission directly from the copyright holder.

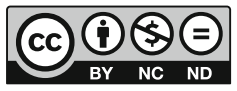

